\title{
Prolínání literatury a etnografie ve Spojených státech amerických
}

\author{
Dominika Ferens
}

DOI: 10.21104/CL.2016.3.04

\section{Intersections of Literature and Ethnography in the United States}

\begin{abstract}
This article argues for the need of a rapprochement between scholars who study ethnographic and literary ways of knowing minority communities that have limited access to self-representation. While in the past literary critics and cultural anthropologists tended to emphasize their distinctive methodologies and conventions of writing about such communities, this article draws on the work of postmodern anthropologists, critical theorists, literary critics, and historians to demarcate the common ground between ethnography and literature. Through the efforts of Clifford Geertz, James Clifford, Mary Louise Pratt, George Marcus, Michael Fisher, and many others, cultural anthropology has, at least to some extent, come to terms with the limitations of participant observation and the textuality of its product. However, a parallel reckoning has not taken place within literary studies. It is the goal of this article to push the process a step further by emphasizing the mutual indebtedness of literary and ethnographic writing.
\end{abstract}

Keywords ethnography, autoethnography, literature, knowledge, cultural patterns, singularity.

Tento příspěvek je revidovanou verzí části mé studie Ways of Knowing Small Places: Intersections of American Literature and Ethnography since the 1960s (Wydawnictwo Uniwersytetu Wrocławskiego, 2010)

Contact dr hab. Dominika Ferens, prof. UWr, Institute of English Studies, University of Wroclaw, ul. Kuźnicza 22, 50-138 Wroclaw, Poland; e-mail: dferens@poczta.onet.pl.

Jak citovat / How to cite Ferens, Dominika. (2016). Prolínání literatury a etnografie ve Spojených státech amerických. Český lid 103, 395-418. doi:http:// dx.doi.org/10.21104/CL.2016.3.04 
$V$ polovině šedesátých let jsem se rozhodla navázat na bakalářská studia literatury a získat doktorát v oboru antropologie. Na první hodině se jedna spolužačka zeptala naší vyučující, která proslula svou průkopnickou prací na poli africké etnografie, $v$ čem vidí rozdíl mezi etnografií a románem. Vyučující odpověděla stroze, netrpělivě a pohrdlivě: "Jestli to nevíte, pak tady nemáte co dělat.“ Spolužačka odpadla po prvním čtvrtletí, stala se vůdčí postavou protiválečného hnutí a spoluzaložila ženské osvobozenecké hnutí na západním pobřeží USA. Vyučující odešla do penze. A já o rozdílech mezi etnografii a románem přemýšlím už přes třicet let. Janet Tallman, „The Ethnographic Novel“ (2002: 10).

Přestože se etnografie a literatura pohybují v kontinuu, kdykoli dojde $\mathrm{k}$ jejich záměně, vyvolá to $\mathrm{v}$ řadách odborníků nelibost. Na samém konci kontinua se nacházejí zarytí puristé, kteří si pole své působnosti obehnali ostnatým drátem. Jedna skupina takových puristů rozbila tábor na konci 19. století, kdy se antropologie stala akademickou disciplínou a její provozovatelé1 se vymezili proti „amatérům“: píšícím cestovatelům, misionářům a regionálním autorům. Tábor literárních puristů má své počátky v 30. a 40. letech 20. století, kdy se stoupenci nového kriticismu rozhodli prosazovat jedinečnost a osobitost literatury v opozici k ostatním kulturním diskurzům. ${ }^{2}$ Mlhavý prostor mezi těmito dvěma tábory obývají ti, kteří si vzájemně lezou do zelí, bud' z toho důvodu, že odmítají vidět rozdíly, nebo proto, že nesouhlasí se způsobem, jakým jsou tyto rozdíly konstruovány. Často se jedná o spisovatele, kteří používají literární diskurz k odhalení fikce v sociální vědě, nedisciplinované antropology, kteří dočasně rezignovali na objektivní podávání zpráv a uchýlili se k subjektivnějším

1 Jeden z otců zakladatelů americké antropologie Franz Boas nabádal své studenty, aby se vyvarovali mísení laické a profesionální etnografie: „Čím větší veřejný zájem o vědu a čím méně technických znalostí je zdánlivě potřeba, tím více hrozí, že se studium zvrhne v populární přednášky. Antropologie patří k vědám, kde je takové nebezpečí bezprostřední a kde je proto nutné s velkou pečlivostí chránit čistě vědecký zájem.“ (Franz Boas citován in Stocking 1992: 8) Jak naznačuje epigraf z „The Ethnographic Novel“ Janet Tallmanové, v 60. letech 20. století byl rozdíl mezi legitimním akademickým diskurzem a fikcí stále vnímán jako propastný. Rozlišování těchto kategorií zůstává v zájmu univerzitních antropologů do dnešního dne.

2 Přestože o čistotu literatury usilovali nejprve formalisté, v pozdější době se k nim přidali někteří menšinoví spisovatelé, kteří se příležitostně dovolávají étosu „čisté literatury“ v sebeobraně, protože se cítí stejně omezováni těmi, kteří je zatěžují odpovědností za reprezentaci svých minorit, jako těmi, kteří si cení více autentičnosti a etnografické přesnosti jejich tvorby než její umělecké stránky. Mezi autory, kteří se pokusili zbavit břemene etnické reprezentace, patří Mei-mei Berssenbruggová, Li-Young Lee a David Wong Louie (viz rozhovory in King-Kok Cheung, Words Matter, 2000). Když byla v roce 1998 odebrána cena za literaturu udělovaná Asociací pro asijsko-americká studia Lois-Ann Yamanakové vzhledem k námitkám, že Yamanaková ve svých knihách neustále očerňuje Filipínce, podepsalo se pod dopis na její obranu osmdesát dva amerických spisovatelů asijského původu, kteří prohlašovali, že autoři beletrie si na rozdíl od sociologů mohou dovolit básnickou licenci a z toho, jak zobrazují různé rasy a etnika, se nemusí nikomu zpovídat (viz Huang - Nelson 2003: 321). Frank Chin se naopak pokusil zdiskreditovat Maxine Hong Kingstonovou tím, že ji obvinil z psaní „popkulturní antropologie“ (Kim 1982: 198). 
žánrům, jako jsou autobiografie a beletrie, nebo o př́slušníky minoritních skupin, které etnografie obvykle objektifikuje a kteří si pro sebe uzurpovali moc obsaženou v reprezentaci, aby s její pomocí vytvořili kontradiskurz.

Tato úvaha o prolínání etnografie a literatury začíná v 60. letech, protože toto desetiletí bylo vskutku přelomové. Ve světě nabírala spád dekolonizace a ve Spojených státech sílilo hnutí za občanská práva Afroameričanů. A tak se stalo, že otázka, kdo má právo koho reprezentovat (v politice, ve vědě, v umění i v literatuře), náhle nabyla na výbušnosti. Válka ve Vietnamu, různé feministické proudy a sled homofilních, gay, lesbických a queer hnutí se vzájemně ovlivňovaly a dokázaly zpolitizovat nevídané množství lidí. Když byl v roce 1965 schválen nový imigrační zákon, který nahradil legislativu upřednostňující migranty z Evropy, do Spojených států začalo přicházet mnoho lidí ze zemí třetího světa. Výsledkem byly demografické změny, které posílily odhodlání minorit postavit se bílé hegemonii. Přizpůsobování se normám bílé střední vrstvy začalo být mnohými vnímáno jako neopodstatněné mimikry; etnická odlišnost měla být důvodem k hrdosti, přestože na rasové hierarchii se prakticky nic nezměnilo.

Psaní o lidech jiné barvy pleti bylo až do pozdního 19. století doménou bílých autorů a poté antropologů či sociologů. Jen málokterý Američan černé pleti měl přístup ke studiu sociálních věd a veškerá černošská literatura podléhala tržním tlakům. Ale v 60. letech 20. století začali na americké univerzity proudit netradiční studenti - lidé jiné barvy pleti a ženy. V roce 1968 se na Státní univerzitě v San Francisku otevřel program etnických studií, o rok později se v důsledku masových studentských stávek přidaly Kalifornská univerzita v Berkeley a Kalifornská univerzita v Los Angeles a brzy se připojily další školy. At' už se tito studenti, kteří bývali předmětem etnografického pozorování, věnovali výzkumu v oblasti sociálních věd, nebo studovali literaturu či kreativní psaní, začali si osvojovat nové diskurzivní a akademické způsoby, jak zasahovat do tradic etnografické reprezentace, překrucovat je a pohrávat si s nimi. Tyto možnosti sahaly od autoetnografie (reprezentace sebe sama a vlastní skupiny) přes kontra-etnografii a parodickou etnografii (obracení perspektivy, kdy je dominantní skupina podrobena etnografickému hodnocení) po anti-etnografii (naprosté odmítnutí účastnit se etnografické hry). Sílila pozice ženské a menšinové literatury: školy pod tlakem periodicky se opakujících hádek o literární kánon neochotně rozšířily seznam povinné četby o „reprezentativní“ texty.

Jak se vyjádřil historik James Clifford, zjištění, že antropologie je „zapletená do světa stálých a měnících se mocenských nerovností“ a „nemůže již promlouvat na základě automatické autority“, vyvolalo disciplinární crise de conscience (Clifford 1986: 9). V tomto ohledu je př́íznačné, že když antropolog Michael J. Fisher v roce 1986 studoval stávající etnickou beletrii vydávanou ve Spojených státech, uzavřel svůj čtyřicetistránkový esej poznámkou, že se jeho disciplína svým způsobem ocitla na vedlejší koleji. Nebyl přitom prvním 
antropologem, který k literatuře z pera autorů jiné barvy pleti přistupovat vážně: na katedře sociologie Chicagské univerzity ${ }^{3}$ se kurzy etnických literatur vyučovaly mnohem dříve, než se staly běžnou součástí studia na katedrách anglistiky (Capetti 1993: 31). Ale zatímco chicagští etnografové četli etnickou beletrii jako zásadní materiál potřebný k dalšímu výzkumu, Fisher v ní hledal metodologické a akademické postřehy:

\section{Stejně jako cestopisy a etnografie sloužily ke zkoumání „primitivního" světa (...) a realistický román sloužil ke zkoumání buržoazních způsobů a ega v raně industriální společnosti, tak mohou etnické životopisy a autobiografická beletrie sloužit jakožto zásadní způsob, jak zkoumat pluralistickou, postindustriální společnost pozdního dvacátého století. (Fischer 1986: 195)}

Fisherovo prohlášení sice nezpůsobilo okamžité zrušení kateder antropologie a jistě ani nepřesvědčilo většinu antropologů o zastaralosti metod a postupů vyvinutých ke studiu kultur. Přesto však bylo známkou, že si američtí antropologové čím dál jasněji uvědomují nedostatečnost nástrojů, s jejichž pomocí se pokoušejí hodnotit kultury a národy, které dávno nesídlí tam, kde kdysi, a odmítají zůstat v klidu na místě, aby mohly být pozorovány.

O tom, jak se sociální vědy opakovaně pokoušely vysvléknout ze staré kůže a přizpůsobit se novému společensko-politickému kontextu, svědčí už vlastní názvy proslulých antropologických a sociologických publikací vydaných po roce 1960: Reinventing Anthropology (Antropologie jinak), The Death of White Sociology (Smrt bílé sociologie), Decolonizing Methodologies: Research and Indigenous Peoples (Dekolonizování metodologie: Výzkum a původní národy), Anthropology as Cultural Critique (Antropologie jako kulturní kritika), Writing Culture: The Poetics and Politics of Ethnography (Psaní kultury: Poetika a politika v etnografii), Women Writing Culture (Kultura ženského psaní). Někteří badatelé se zakopali na svých pozicích a usilovali o ještě nekompromisnější vědecké standardy; jiní se váhavě chopili nekonvenčních nástrojů a žánrů, včetně autobiografií a etnografické beletrie, které využívali k sebereflexi a přehodnocení své disciplíny. Autobiografie a beletrie byly prostředkem, jenž umožňoval pokračovat v mezikulturním zkoumání za nových podmínek, bez autority plynoucí z vědeckého bádání. Mnozí obrátili svou pozornost ke komunitám ve Spojených státech, například $k$ většinově bílému venkovu a důlním městečkům, potravinářským družstvům, „newageovým“ zdravotním centrům 
či městkým ghettům. ${ }^{4}$ Když kulturní antropologie ztratila podporu ve třetím světě a méně postgraduálních studentů mohlo odjíždět na stáže do zahraničí, zájem o studium klesl. ${ }^{5}$ Někteří z těch, kteří by se bývali stali sociology, raději odešli a studovali angličtinu nebo kreativní psaní, včetně Paule Marshallové a Russella Leonga, kteří se posléze stali slavnými spisovateli. Stovkám dalších dodal odvahu úspěch Alice Walkerové, Toni Morrisonové, Maxine Hong Kingstonové a Leslie Marmon Silkové a pokoušeli se uživit psaním.

Humanitní a sociální vědy mezitím vstřebaly kritické teorie Jacquese Derridy, Louise Althussera, Michela Foucaulta, Pierra Bourdieuho i takových feministických filozofek, které zpochybňovaly převládající epistemilogické předpoklady, jako byly Nancy Hartsocková, Sandra Hardingová a Donna Harawayová. Literární kritik Ryszard Nycz se na desetiletí, která následovala, dívá jako na dobu poznamenanou na jedné straně rozvojem estetizace kulturní reality a sklonem číst kulturu jako text a na straně druhé „,rekulturizací‘ (kontextualizací) literatury, která se tak znovu stává jednou z diskurzivních praktik kulturní reality“ (Nycz 2006: 31).

Přemítání o tomto dějinném a teoretickém vývoji přivedlo Clifforda v roce 1986 k načrtnutí působivých geografických metafor: „Došlo ke koncepčnímu posunu, jehož dopady jsou ,tektonické‘. Nyní stavíme na pohyblivé půdě. Už neexistuje žádná vyhlídka (vrcholek hory), z níž bychom mohli získat přehled o životním stylu, žádný Archimedův bod, z něhož bychom viděli obraz světa. Hory jsou v neustálém pohybu. A ostrovy také: protože člověk nemůže otevřeně obývat omezený kulturní svět a vystupovat $\mathrm{z}$ něj pouze proto, aby analyzoval jiné kultury.“ (Clifford - Marcus 1986: 22)

Je příznačné, že ostrovy patřily ke klíčovým místům, která přispěla k rozvoji západních akademických metod a postupů uplatňovaných při systematickém studiu nezápadních národů. Profesionální antropologové jezdili na počátku 20. století na ostrovy s přesvědčením, že představují ekvivalent biologických laboratoří - že jsou dokonalou rezervací „primitivního“ a nabízejí největší možný kontrast vůči „modernímu“. V praxi to znamenalo, že kultury začaly být vnímány jako neměné, nehybné a uzavřené na nevelkém území. ${ }^{6}$ Etnografové měli sklony podporovat evoluční paradigma, podle něhož je

Viz například příspěvky v Anthropologists at Home in North America (1981), ed. Donald A. Messerschmidt. Viz např́lklad New Perspectives in Cultural Anthropology (1971) Rogera a Felixe Keesingových a Messerschmidtův úvod in Anthropologists at Home (1981).

Arjun Appadurai v eseji „Putting Hierarchy in its Place“ zproblematizoval skutečnost, že pro tradiční etnografii „nejsou domorodci pouze osobami pocházejícími z určitých míst, osobami, které na tato místa patří, ale také těmi, kteří jsou na těchto místech uvěznění či zavření", zatímco antropologové sami sebe považují za mobilní a nepřipoutané ke konkrétnímu místu (Appadurai 1988: 37). Tuto otázku rozvedl James Clifford ve studii z roku 1997 nazvané Routes: Travel and Translation in the Late Twentieth Century, v niž si pokoušel představit etnografickou praxi narušující staré paradigma. James Buzard v eseji „On Auto-Ethnographic Authority“ z roku 2003 zase upozornil na fakt, že „domorodí“ etnografové či „autoetnografové“ mají sklony nevědomky pokračovat v zobrazování vlastních etnických skupin jakožto odloučených enkláv, aby si vybudovali autoritu, která jim umožní tyto skupiny zastupovat. 
kultura jednotná a západní národy stojí na vrcholu (ačkoli funkcionalismus, vzorce kulturní antropologie a konfiguralismus přicházely s méně teleologickými alternativami), dokud jim zvěrstva druhé světové války neposkytla důkazy o opaku. Jestliže například Margaret Meadová zatoužila lépe porozumět problémům amerických adolescentů, nejela „do Německa nebo do Ruska, ale na polynéský ostrov Samoa ležící přibližně třináct stupňů na jih od rovníku“, protože si, jak vysvětlovala,

nevyberme prostou rolnickou komunitu v Evropě ani skupinu bílých horalů na izolovaném americkém Jihu, nebot životní styl těchto lidí patř́ navzdory své jednoduchosti ze své podstaty k historické tradici, $k$ níž náležejí komplexní oblasti evropské a americké civilizace. Raději volíme primitivní skupiny, které se po tisíce let vyvíjely úplně jinými směry než my, jejichž jazyk nezná indoevropské kategorie, jejichž náboženské představy jsou jiné povahy, jejichž společenská organizace je nejen jednodušší, ale rovněž velice odlišná od naší. $Z$ těchto kontrastů, které jsou natolik sugestivní, že člověk zvyklý na náš životní styl žasne a nachází v nich poučení, a současně dostatečně jednoduché na to, aby se daly rychle pochopit, se můžeme přiučit mnoha věcem o dopadech civilizace na jednotlivce, kteří v ní žijí. (Mead 1973: 5)

Tichomoří, Karibik a další ostrovy patřily po desetiletí k nejoblíbenějším místům etnografického bádání, přestože práce v terénu probíhala také v Africe, Stř̌ední a Jižní Americe, Austrálii a na Aljašce. Ale tato ostrovní studia zůstávala paradigmatická a akademici nadále vyhledávali malé, kulturně homogenní komunity, které měly minimální kontakt se západní kulturou. Ostrované z Tichomoří, Karibiku a dalších míst si nemohli dovolit reciprocitu. Jak upozornila Sandra Hardingová, v 19. století „byla malá šance, že by do Paříže, Londýna nebo Berlína přijel studovat domorodec a posílal domů zprávy o podivných názorech a chování, z nichž se skládá ,kmenový život‘ evropských antropologů“ (Harding 1991: 155). Koloniální přesuny bílých obyvatel do třetího světa předcházely opačným přesunům lidí z třetího světa do metropolí 20. století. Časem se tito migranti a jejich potomci začali pokoušet o změnu asymetrie v přístupu k textové reprezentaci, politické moci a ekonomickým zdrojům.

Fiktivní narativy zasazené do prostředí vzdálených ostrovů často svádějí k etnografickému čtení. At již je ostrov vykreslován jako utopie, tichomořský ráj nebo pozůstatek doby kamenné, domov záludných sirén, vznešených divochů, kanibalů či smyslných panen, je místem, kde se soustředí zásadní rozdíly, na nichž jsou usazené vrstvy západních kulturních asociací.7 Ostrov,

7 Viz například: Greg Denning, Islands and Beaches: Discourse on a Silent Land, Marquesas 1774-1880 (1980); Rod Edmond a Vanessa Smith, Islands in History and Representation (2003); Diana Loxley, Problematic Shores: Literature of Is/ands (1990). 
oddělený od okolí a s jasnými hranicemi, se zdál být z jednoho kusu, pochopitelný, čitelný, stabilní a neměnný. Někteří z prvních antropologů s ostrovy nakládali jako s laboratořemi či stroji času, které jim zprostředkovávaly př́ímá setkání s prehistorií „západní civilizace“. Ale aby se k nim etnografové mohli chovat jako k neposkvrněným, izolovaným laboratořím, museli přehlížet často složité dějiny mezikulturních kontaktů, k nimž došlo před jejich př́ijezdem, i vlastní přítomnost, která kontaminovala zkoumaný terén. Jejich posláním bylo „zachránit“ pro západní archivy písemné záznamy kultur, jež byly údajně předurčené k zániku - kultur, které byly cenné a zajímavé právě proto, že brzy zaniknou nebo projdou změnou zásluhou kontaktu s modernitou. ${ }^{8}$

Psaní z ostrovů či jiných malých oblastí nebo psaní o nich za účelem publikace v amerických metropolích nutí autory vzít v potaz zájmy a očekávání čtenáře, které se mohou výrazně lišit od zájmů a očekávání obyvatel malých, geograficky vzdálených míst či přistěhovaleckých komunit ve Spojených státech. V posledních desetiletích je zájem obyčejných Američanů o taková místa formován multikulturalismem. Ten představuje vzdělávací politiku a signalizuje všem Američanům, že by se měli vystavit „etnickým“ rozdílům a vyzkoušet menšinové literatury po způsobu, jakým ochutnávají kimči, zapékaný jam nebo baklavu. Každou minoritu obvykle na seznamech povinné četby středních a vysokých škol zastupuje jediný literární hlas, podobně jako si tradiční antropologie vystačila s jednou monografií na každý ostrov. Platí pravidlo, že experimentální a non-narativní spisovatelé nejsou chápáni jako „reprezentativni““, a proto je nad poezií upřednostňována beletrie.

Pravda, mnohá díla amerického literárního kánonu také vyprávějí o „malých místech“. Místa těšící se etnografickému zájmu nemusí být nutně ostrovy v geografickém smyslu obydlené lidmi jiné barvy pleti. Exotickou přitažlivost mají i jiné odlišnosti. Edith Whartonová např́íklad proměnila v předmět etnografického zkoumání newyorskou vyšší třídu. Byla povzbuzena Henrym Jamesem, aby „udělala New York“(James citován in Bentley 1996: 2), tedy aby prozkoumala zvyky a způsoby kmene, který zná nejlépe. ${ }^{9}$ Ale pochází-li subjekt a objekt etnografie i její zamýšlené publikum z bílé (a vyšší) stř̌ední třídy, mocenská asymetrie je vynulována. Kdyby se „domorodcům“ Edith Whartonové zdálo, že je zobrazila neuspokojivě, mohli si vydat vlastní, konkurenční knihy. Ve skutečnosti už byla tou dobou řada takových děl v oběhu.

8 Viz například: Johannes Fabian, Time and the Other (1983); Marianna

Torgovnick, Gone Primitive (1990). Ohledně etnografie jako „záchrany“ viz

článek Jamese Clifforda „The Others: Beyond Salvage Paradigm“ (1989).

9 Nancy Bentleyová předložila podrobnou analýzu díla Edith Whartonové, které označila za etnografii newyorské vyšší třídy. „Porozumět fikci v mé studii (...) znamená pochopit, co znamená udělat fikci, k jaké společenské a estetické funkci zde dochází,“ vysvětluje Bentleyová. „Za účelem analýzy fikce jako praxe, jako způsobu, jak na stránce ovládnout způsoby, zkoumám sbližování románů a etnografických textů a jejich spolupráci při napomáhání vzniku našeho moderního kulturního diskurzu. Tato spolupráce nám pak otevírá nové dějinné a kritické pohledy na ono výjimečné ovládnutí způsobů, jimiž je psaní beltrie“ (Bentley 1995: 2-3). 
Podobně se to má s narativy Sherwooda Andersona či Dona DeLilla zobrazujícími malé komunity: také tato díla soupeří na knižním trhu se stovkami jiných zobrazení bílého amerického Středozápadu. Na papíře vyšlo tolik verzí ohijského Winesburgu a provinčních univerzit, že by byla pošetilost považovat tyto obrazy za zdroj etnografického poznání Euro-Američanů. Beletrie z pera Američanů jiné barvy pleti, kteří ve svých menšinách patřili k prvním, kdo dosáhl uznání - Sui Sin Farová, Zora Neale Hurstonová, Richard Wright, N. Scott Momaday, Maxine Hong Kingstonová nebo Rodolfo Anaya -, byla ovšem etnografickou reprezentací nadále zatěžována. ${ }^{10}$ Tito spisovatelé se dočkali uznání zejména (byt ne pouze) proto, že přenášeli čtenáře na místa, jimž ti se ve skutečném životě vyhýbali a o nichž se málokdy psalo: do ghett, rezervací, čínských čtvrtí, černošškých měst či hispánských periferií. Během let výše zmínění i další autoři jiné barvy pleti publikovali bezpočet textů; čtenáři se seznámili s odlišnými metodami reprezentace a začali si více všímat úhlu pohledu, hlasu, vypravěčského postupu, použití ironie, parodie a dalších formálních strategií. Nicméně běžného amerického čtenáře stále láká to, čemu literární kritička King-Kok Cheungová říká „silný ,etnický“ kvocient“ (Cheung 2000: 19). Malá místa jsou vždy chápána jako „specifická“ a nemohou si nárokovat stejnou „univerzálnost“ jako Andersonův Winesburg nebo DeLillova provinční univerzita. ${ }^{11}$ Asymetrie mezi malými a velkými místy v politickém a literárním smyslu přetrvává.

Etnografie (ve formě cestopisu, beletrie nebo monografie) je intertextem mnoha amerických fikcí. Šírit povědomí o cílech, metodách a hlavních zájmech etnografie je tedy přínosné už proto, že nám taková znalost umožní nacházet v literárních textech jistá přetrvávající témata, diskurzivní napětí a formální inovace, jež bychom jinak nepostřehli. Dalším důvodem, proč čerpat z práce historiků a kritiků etnografie, je skutečnost, že jejich teorie „způsobů poznání“ jsou vzhledem k epistemologické krizi v sociálních vědách systematičtější než práce literárních teoretiků. Jestliže jsou literární obrazy rasových/kulturních rozdílů často čteny etnografickou optikou, jak to zde tvrdím, potom může porozumění rozvinuté v rámci sociálních věd posloužit ke zproblematizování vztahu menšinových literatur k vědění.

Prolínáním literárních studií a antropologie se v posledních letech zabývalo několik polských literárních vědců - zejména Michał Paweł Markowski, Ryszard Nycz, Andrzej Mencwel, Anna Łebkowská a Anna Burzyńská -, kteří se nechali inspirovat (či vyprovokovat) takovými postmoderními teoretiky jako Clifford Geertz, Richard Rorty a Jacques Derrida, teoretiky zkoumajícími čtenářské reakce Stanleyem Fishem a Wolfgangem Iserem, Birminghamskou

10 V Edith and Winnifred Eaton: Chinatown Missions and Japanese Romances (Ferens 2002) jsem podrobně popsala skutečnost, že běžní američtí čtenáři nepřestávají číst knihy Sui Sin Farové jako etnografické příběhy. Existuje nesčetně důkazů, že totéž dnes platí pro většinu beletrie psané autory jiné barvy pleti. 
školou a feministickými teoriemi. „Kulturní teorie literatury“ předkládaná Nyczem i jeho vysoké hodnocení „mezioborovosti“ mi dává volnou ruku přemýšlet o problémech, které vyplují na povrch, když se literatura chová jako etnografie, je za etnografii považována, nebo když se etnografie chová jako literatura. Jenže vzhledem k hledání teorií, které by mohly oživit studium středoproudé polské literatury, a $\mathrm{k}$ faktu, že problém rasové reprezentace v polském bádání prakticky neexistuje, mají tyto přístupy pro daný projekt pouze omezenou relevanci. Pokud vím, jedinou polskou amerikanistkou, která se věnuje studiu prolínání literatury s etnografií, je Agata Preiss-Smithová. Ale ve světle rychle se měnící rasové demografie východní/střední Evropy si etnografie ani literatura nemohou dovolit přehlížet rasovou kategorii donekonečna.

Body, v nichž se etnografie a literatura stýkají a rozcházejí, by měly být patrné ze stručného přehledu dvojího způsobu psaní (a poznání). Etnografií se všeobecně rozumí akademický text založený na „výzkumném procesu, v jehož rámci anropolog detailně pozoruje a zaznamenává každodenní život v jiné kultuře a zapojuje se do něj“, aby posléze „poskytl své osobní a teoretické úvahy odborníkům i čtenářům z řad veřejnosti“ (Marcus - Fischer: 1986: 1718). Předpokladem existence tradiční etnografie je fyzická vzdálenost a rozdíl v poznání mezi předmětem zájmu a čtenáři. Etnograf vystupuje jako prostředník, který má výsadní přístup na místa, na která většina z jeho čtenářu patrně nikdy nezavítá. Tranzitním rituálem každého antropologa je terénní praxe na vzdáleném místě, spočívající v „participačním pozorování“. Za otce tohoto rituálu je považován Bronisław Malinowski, který se po první světové válce vrátil z Melanésie a začal působit na Vysoké škole ekonomické v Londýně. V úvodu ke knize Argonauti západního Pacifiku definoval přímé setkání s jinými lidmi a pokus „porozumět“ jejich kultuře jakožto morální imperativ seriózního badatele: „Etnograf má v terénu (...) povinnost sepsat všechna pravidla a zvyky kmenového života, všechno, co je stálé a neměnné; má povinnost dát domorodé kultuře anatomii, popsat skladbu společnosti“ (Malinowski 1984: 11). „Porozumění“ exotické kultuře a „šíření povědomí“ (Graham Watson citován in Wolf 1992: 1) se stalo sekulární misí britských a amerických etnografů, kteří doufali, že takové poznání otevře západní ego obohacujícímu vlivu jiných kultur a poskytne jim referenční body pro přehodnocení západní kultury. Co může etnografie udělat lidem či pro lidi, jimiž se zabývá, nikoho př́liš nezajímalo. Etnografové neuvažovali nad tím, zda jejich práce prospěje původnímu obyvatelstvu; na zřeteli měli západní publikum, a to i tehdy, byla-li jejich motivem „záchrana“ předmoderních kultur před parním válcem moderní doby. Horentse Powdermakerová se ještě v roce 1968 vyjádřila následovně: „Primárním zájmem antropologa není pomáhat svým informátorům, byt tak může bezděčně činit. Jeho motivací je shromažd'ovat fakta." (Powdermaker 1966: 296)

Taková představa o vztahu mezi subjektem a objektem etnografie vzala za své, když nově dekolonizované národy na jedné straně a feministky 
a Američané jiné barvy pleti na straně druhé odmítli hrát přidělené role. ${ }^{12}$ „Má terénní praxe se na hony lišila od terénní praxe, z níž se zrodila moderní antropologie,“ napsala Američanka kubánsko-židovského původu Ruth Beharová, „od té, kdy se jeden stáhl do nejvzdálenější vesnice, jakou našel, nebo se nechal uvěznit na ostrově a vzal na sebe heroickou úlohu etnografa, čnícího nad všemi nezasvěcenými a nad všemi elitami z titulu vyššího poslání.“ (Behar 1996: 243) Také Pnina Motzafi-Hallerová, Izraelka orientálního původu, která studovala ve Spojených státech, hledala cesty, jak se vyhnout „esencializaci svých lidí“ (Motzafi-Haller 1997: 215). „Jestliže se ocitnete uvnitř marginalizované komunity,“ zjistila Motzafi-Hallerová, „ovlivňuje to nejen vaše badatelské zájmy a epistemologie, které si k takovému bádání zvolíte, ale také se tím s vaším vědomím a/nebo bez něj zvyšuje vaše citlivost vůči praktikám vylučování, což vás možná dovede $\mathrm{k}$ tomu, abyste ve svých textech nepřijímali status quo“ (1997: 216). Etika takového „porozumění“ kulturám se v době po boji afroamerického hnutí za občanská práva jevila podezřelou, stejně jako cíl shromaždovat kulturní poznatky na západní akademické půdě, což byla praxe, která nedbala na blahobyt zkoumaných subjektů, přestože jejich existence na okraji globálního kapitalismu byla čím dál nejistější.

Tradiční britští a američtí etnografové se rozdělovali podle výzkumných témat či problémů. V 19. století vyšel přehled výzkumných témat v příručce Notes and Queries on Anthropology (Poznámky a otázky pro antropologii), ${ }^{13}$ která byla pravidelně revidována v reakci na aktuální teoretické diskuse. Etnografové se učili hledat kulturní vzorce a přehlížet ojedinělé události. „Vždy se mi př́čilo, jestliže se někdo pozastavoval nad svérázným, výjimečným faktem, bavil se jím a vnímal jeho vnější zvláštnost, díval se na něj jako na kuriozitu a ukládal jej do muzea vlastní paměti či do sbírky historek,“ napsal Malinowski. „Takový přístup mi byl cizí.“ (1984: 517) Etnograf, od něhož se očekávalo, že objeví kulturní vzorce, čímž „potlačí rozpaky a údiv“ (Geertz citován in Wolf 1992: 128), si nemohl dovolit ztrácet čas s ojedinělostmi.

12 Henry Yo v kritických dějinách výzkumu věnovaného Američanům asijského původu, který prováděla katedra sociologie Chicagské university, dokládá, že v první polovině 20. století nebílí etnografové a jejich informátoři skutečně hráli přidělené role (2001: 93-150). Studenti antropologie jako Paul Siu, Rose Hum Leeová nebo Frank Miyamoto patří k mnoha badatelům z řad menšin, kteří studovali v první půli 20. století a dle očekávání se zabývali vlastními přistěhovaleckými komunitami. Pokud měli tytéž výhrady, jaké v následujících generacích vyjadřovali akademici jako Motzafi-Hallerová a Beharová, pak se jim zdálo, že jim nepř́isluší protestovat. Jisté je, že internovaní Japonci, které za druhé světové války studoval (taktéž internovaný) Miyamoto, nebyli v pozici, kdy by mohli cokoli namítat proti způsobu, jakým Ruth Benedictová zneužila jejich výroky k závěru, že japonská kultura je v naprostém rozporu s kulturou americkou. Viz Geertz (1984: 102-128), který podává poutavou analýzu díla Ruth Benedictové The Chrysanthemum and the Sword: Patterns of Japanese Culture.

13 První vydání prríručky Notes and Queries připravili britští antropologové v roce 1874. Př́ručka měla sloužit laikům (včetně cestovatelů, misionářů a koloniálních správců) ke sběru etnografických dat. Skládala se z dlouhého seznamu otázek rozdělených podle takových témat, jako byla „tělesná charakteristika“ nebo "jazyk“. Poslední (šesté) vydání bylo publikováno v roce 1951. Ohledně diskusí k různým vydáním příručky viz Dan Rose (1993: 209-210). 
Vzhledem k tomu, že se etnografický popis zaměřoval spíše na typické chování než na to, co badatel viděl někoho dělat při zvláštní př́ležitosti, obvykle se používal tzv. etnografický prézens. Malinowski to vyjádřil bez obalu: „Nezajímá nás, co A nebo B cítí jakožto jedinec, nezajímá nás náhodný běh jeho osobní zkušenosti - zajímáme se pouze o to, co cítí a co si myslí jakožto člen dané komunity“ (1984: 23). Dokonce i tehdy, kdy bylo proklamovaným cílem podat zprávu „o myšlení domorodců“, se autorita badatelových textů a závěrů opírala o tvrzení, že badatel rozumí „domorodcům“ lépe než oni sami. Když se Edith Turnerová zamýšlela nad strukturalisticko-funkcionalistickou průpravou, jíž prošla před několika desetiletími, s překvapením konstatovala: „Na základě mnoha zážitků, statistik a zaznamenaných událostí mohl být získán zdánlivě ucelený obraz [kultury]. Materiál jsme rozdělovali do kolonek, jako bylo prostředí, obživa, společenská struktura, rodinná pravidla, hospodářská výměna, náboženská změna, konflikt a nepřizpůsobivost.“ (Turner 1993: 30) Jak tyto kategorie napovídají, soubor etnografických textů byl ilustrativní, ale scházelo mu chronologické řazení. Jestliže měl etnograf potřebu rozepsat se o svém příjezdu na místo a o tom, jak poznal místní obyvatele, učinil tak pouze v rámci úvodu, doslovu nebo poznámek pod čarou.

Od 80. let 20. století vyvíjejí američtí etnografové soustředěné úsilí, aby svou disciplínu přetvořili s pomocí poznatků z kritické teorie, kulturních a etnických studií, feministické a queer teorie. $\mathrm{O}$ tom, k jak nesmírným změnám v teorii a metodologii došlo, se můžeme přesvědčit, když si prohlédneme standardní učebnice americké či britské kulturní antropologie/kulturologie vydané kolem roku 1960 a později. ${ }^{14}$ Ale přestože etnografické axiomy (včetně nepodstatnosti ojedinělostí) byly revidovány, etnografie stále pátrá v každodenní sociální interakci po kulturních vzorcích. ${ }^{15}$ Jejím hlavním cílem je koneckonců „potlačit rozpaky a údiv“ a objevit „neoficiální logiku skutečného života“ (Geertz citován in Wolf 1992: 128).

Literatura může být stejně jako etnografie chápána coby způsob, jak se setkávat s jinakostí, at už je za ni považována neznámá kultura, nebo něco blíže domovu - ale za horizontem naší intelektuální či estetické zkušenosti, či

14 Viz např́ílad Felix M. Keesing, Cultural Anthropology: The Science of Custom (1958); Roger M. Keesing a Felix M. Keesing, New Perspectives in Anthropology (1971); Richley H. Crapo, Cultural Anthropology: Understanding Ourselves and Others (1990); Harry F. Wolcott, Ethnography: A Way of Seeing (1999) a David M. Fetterman, Ethnography (1998). V roce 1958 Keesing prezentoval antropologii jako „vědu“ a soustředil se především na kultury třetího světa, ale v roce 1990 už tato představa nebyla všeobecně přijímána; Crapo zůstává věrný názvu své učebnice Understanding Ourselves and Others (Porozumět sobě a druhým) a příklady z nezápadních kultur dorovnává řadou příkladů z kultury západní. Na rozdíl od starších učebnic, které upřednostňují předmoderní kultury, staví do popředí kulturní adaptaci a změnu. „Vzorec" (angl. pattern) je pro antropology klíčovým slovem. Například nejznámější díla Ruth Benedictové nesou názvy Patterns of Culture a Chrysanthemum and the Sword: Patterns of Japanese Culture. A první kapitola knihy Margery Wolfové Revolution Postponed: Women in Contemporary China se jmenuje "The Past and the Pattern". 
dosud neprozkoumaný aspekt vlastního ega. Kde spisovatelé a čtenáři vedou hranici mezi známým a neznámým, je podmíněno stejně tak kulturním zázemím, společenskou vrstvou, pohlavím, rasou a věkem, jako individuální literární zkušeností. Derek Attridge například s odvoláním na Jacquese Derridu a Emmanuela Levinase hovoří o schopnosti literatury „rozvolnit“ „zavedené vzorce duševního světa a normy idiokultury“, což nám umožňuje „přivítat opravdovou jinakost“. Podle Attridge mají opakovaná setkání s jinakostí prostřednictvím literatury potenciál měnit subjektivitu, dokud „není možné říct, že ego je ,výtvorem jiného““ (2004: 24).

Cíleně avantgardní literatura se ze své definice pokouší vytlačit spisovatele i čtenáře za hranice bezpečného, známého světa, ale k setkávání s jinakostí mohou sloužit i populární žánry, jak ukazuje následující vzpomínka antropoložky Margery Wolfové:

Jako dítě vyrůstající $v$ dělnické rodině (...) jsem se zajímala především o romány o ženách. Četla jsem, abych se něco dozvěděla o životě,, který jsem vídala zpovzdálí, ale ke kterému jsem neměla přistup. Věděla jsem, že často čtu „falešné“ př́běhy, ale bylo mi to jedno. Chtěla jsem vědět, jak ženy ve městech nastupují do tramvají, nakupují jídlo a vybírají si př́tele, chtěla jsem vědět, o čem si povídají a tak dále. A chtěla jsem to slyšet od někoho, kdo tam byl, kdo to zažil. (...) Prahla jsem po detailech života, který se mi zdál exotický a vzrušující a které mi (tyto romány) poskytovaly. Ale časem jsem na romány zanevřela - už mi nepřinášely tolik nových informací, aby tím přebily nudné př́běhy. (Wolf 1992: 58-59)

Wolfová jako začínající antropoložka ztratila zájem o dospělé hrdinky z červené knihovny, když se dozvěděla vše, co potřebovala k zaujmutí role městské ženy, a jinakost hrdinek vybledla. Většina americké literatury je psána tak, že ji lze rozřadit do (často nepo̊vodních) žánrů. Ačkoli každý z těchto žánrů setkání s jinakostí tak či onak podmiňuje, přesto některým čtenářům umožňuje, aby jistá setkání zažili.

Při úvahách o rozdílech mezi akademickým a literárním způsobem poznání Attridge vychází z Levinase, který vyčítal vzdělávacím metodám ukotveným v západní filozofii, že jsou „zasvěcené dokonalým znalostem jinakosti, přičemž nenechávají prostor pro překvapení; jenže podle [Levinase] lze skutečného filozofického pochopení, skutečné výuky a skutečného poučení dosáhnout pouze tehdy, pokud nás jinakost překvapuje“ (Attridge 2004: 84). Podle Charlese Bernsteina, dalšího pozorného Levinasova čtenáře, je ideálním způsobem poznání poezie, protože má nekonečnou schopnost překvapovat:

Nikoli jediné cítění, ale střet vjemů: báječná kakofonie rozmanitých těl vydávajících rozmanité zvuky, které se od sebe liší stejně jako 
hukot Hester Street od šumění přehrady Grand Coulee, cvrkot $v$ Central Parku za srpnového odpoledne od křiku ropou znečištěných ptáků v aljašké úžině prince Williama. (Bernstein 1992: 1)

Bernstein věří, že literatura obecně (a poezie obzvláště) nechává prostor pro formální i ideologický nesouhlas a pro mnohost a neurčitost smyslu. Staví se proti „mužské verzi univerzálního hlasu racionality, který se pokouší ovládnout ženská těla jako břichomluvec“ (Bernstein 1992: 5). Poezie hovoří mnoha hlasy a ta nejlepší „obsahuje vícečetné, protichůdné perspektivy, druhy jazyka a typy stylů“ (Bernstein 1992: 2).

Beletrie na pomezí kultur podobně jako etnografie vytváří a interpretuje rozdíly. Jonathan Culler rozvádí teorii Benedicta Andersona o klíčové úloze románu při budování národních identit a upozorňuje na „radikálně odlišné způsoby, jakými se čtenáři románu mohou stát zasvěcenci a cizinci zároveň. Zejména v koloniích či bývalých koloniích se může přihodit, že čtenářova představa národní identity vyroste $z$ vnější vize, když vidí, kde se nachází na mapě.“ (Culler 1999: 38) Potenciál románu Culler spatřuje především v jeho formě a v možnostech (ne)identifikace, které vytváří, než v jeho reprezentativní funkci:

Pro román a způsob, jakým formálně črtá obrazy komunitního prostoru, je charakteristické, že otevřeně vyzívá čtenáre z jiného prostředí, aby se stali zasvěcenci, přestože současně přichází s možnými rozdíly mezi zasvěcencem a cizincem či př́telem a nepř́telem, které se stávají základem politického vývoje. (Culler 1999: 38)

Zatímco etnografové musí prokázat, že mají nad materiálem z terénu plnou kontrolu, chtějí-li, aby je brali vážně, a proto odsouvají stranou nejasné situace a nevyřešená dilemata, spisovatelé obvykle zanechávají čtenáře zmateného nebo zneklidněného. Psát dobře znamená vzdát se tu a tam kontroly, opustit známé jazykové vzorce a vyhýbat se rozřešením. Literatura, zejména poezie, má k jasným závěrům averzi: „Všechno (je) lepší než dobře vypracovaná, předvídatelná, uměřená epifanie - protože praskliny, vady a neobratnosti jsou alespoň známkou života“ (Bernstein 1992: 2). Román, divadelní hra a báseň vyzývají k mísení mnoha hlasů. Jak si povšiml Michail Bachtin, dokonce i ideologicky angažovaný román je dialogický a tudíž vícehlasý.

Paradoxně ovšem, řečeno slovy Elisabeth Frostové, „vnesení etnografie do románu brání experimentování“. Důraz na reprezentativní funkci literatury odrazuje některé autory od toho, aby se věnovali svým formálním zájmům, a ty, kteří se jich nevzdali, nepouští do multietnického kánonu. Frostová upozorňuje, že právě to se stalo Therese Hak Kyung Chaové, autorce Dictee (1982), vícežánrové, vícejazykové a vícehlasé knihy sestavené 
ze střípků mnoha kultur. Protože Chaová rezignovala na „prosazování ,autentického' reprezentativního korejsko-amerického ega, kritici ji nejprve nepřijali““. ${ }^{16}$ Teprve v posledním desetiletí se spolu s dalšími „nereprezentativními“ menšinovými spisovateli dočkala kritické pozornosti, kterou si zaslouží.

Etnografie popisuje charakteristické chování a „osoby se společným jmenovatelem“ (Van Maanen 1988: 49); literatura se oproti tomu vyžívá v ojedinělém, výstředním a podivném - v tom, co nelze jednoduše vysvětlit či redukovat na známý vzorec. Literatura má zpravidla větší zájem o to, co „A nebo B cítí jakožto jedinec“ (Malinowski 1984: 23), než o to, co má cítit pod vlivem své kultury; román se totiž o osobu A nebo B začne zajímat teprve tehdy, když se od své kultury maličko odkloní. Protože je románová forma spojovaná se vzestupem kapitalistické ideologie provázeným zrodem individualismu, má sklon soustředit se na výjimečné postavy, často procházející formováním identity, přestože se od čtenářů očekává, že v některých postavách rozeznají archetypy (že například v Hemingwayově Robertu Cohnovi uvidí odcizeného newyorského žida). Možná, že beletrie má svůj ekvivalent etnografických Poznámek a otázek v implicitních tématech, ale obyčejně je založená na ději a strukturovaná kolem rozvíjejících se postav. Když spisovatel použije přítomný čas, obvykle to dělá, aby vytvořil pocit bezprostřednosti, nikoli proto, aby umístil postavy do ahistorického „etnografického prézentu“.

Ale ohledně jedinečné schopnosti literatury a poezie reprezentovat jinakost bez břichomluvectví či osvobodit nás od starých vzorců myšlení a formy nejsem tak optimistická jako Attridge a Bernstein. Literatura, která se pohybuje mezi kulturami, je předmětem osobitých tlaků a mylného čtení. Jak vysvětluje vietnamská imigrantská spisovatelka Le Ly Hayslipová, tyto tlaky pramení z potřeby smírit „to, co lidé [ve Spojených státech] chtějí, co potřebují vědět a co by vědět měli. Nabízíme něco, čemu by nerozuměli, přestože třeba [ve Vietnamu] žili a pracovali jako vojáci, novináŕi, politici nebo vědci“ (Cheung 2000: 109).

Naopak způsob, jakým James Clifford interpetuje Michela Leirise, Marcela Griaula a Marjorie Shostakovou v knize Predicament of Culture (Dilema kultury, 1988), svědčí o tom, že také etnografie má své praskliny a vady, v nichž se uchytil život, a že formální inovaci lze uskutečnit i v hranicích akademického žánru. Protože se etnografové a spisovatelé proti sobě často vymezovali, je snadné zapomenout na to, jak se vzájemně ovlivňovali a obohacovali. Antropologové často bývali vášnivými čtenáři beletrie, zejména když pracovali v terénu, kde knihy mnohdy nahrazovaly rodinu a přátele. Antropologové také sami psali, at už proto, aby zpopularizovali svá zjištění, nebo aby dali průchod nahromaděným vzpomínkám z terénní praxe, které neměly v oficiální 
etnografii místo, nebo zkrátka proto, že je tvůrčí psaní bavilo. ${ }^{17}$ A literáti jsou zase vystaveni etnografii v mnoha populárních formách, od učebnic zeměpisu přes etnografické filmy až po časopisy a průvodce na cesty.

Tradiční model etnografie spoléhal na existenci mezer ve znalostech a technikách z neznámého učinit známé; nyní, když mnozí etnografové provádějí výzkum „doma“ (na místech, která jsou jejich čtenářům poměrně dobře známá), je obvyčejně cílem jejich práce známé ozvláštnit (a tím pádem z něj učinit něco, co není nevyhnutelné, co je otevřené změně). Na existenci mezer ve znalostech se zpočátku spoléhala také etnická americká literatura: prohlašovala, že reprezentuje „mainstreamovou“ zkušenost „menšinových“ skupin. ${ }^{18}$ Dnes je „mainstream“ většinou jiné než bílé barvy. Samotné „menšinové“ komunity (kterým před padesáti lety mnohdy chyběly peníze na knihy i čtenářská zdatnost) nyní představují významnou čtenářskou základnu etnické beletrie. Autoři se zabývají defamiliarizací známého, reprezentací minoritních skupin určenou pro př́íslušníky vlastní skupiny i mapováním vztahů k jiným skupinám.

V otázce poznání se přístup etnografie a literatury zdánlivě velice liší. Etnografie vynáší seriózní prohlášení a musí shromáždit, roztřídit a interpretovat údaje, aby své výroky doložila; a protože se snaží o objektivitu, musí neustále zpochybňovat vlastní skryté domněnky. Literatura si naopak nedělá na objektivitu žádný nárok (přestože jí velmi zálěží na poznatcích), a proto má svobodu využít k vtažení čtenáře do díla jakýchkoli prostředků; ojedinělost, zaujatost a subjektivita jsou znamením její síly, nikoli slabosti.

Některá literární díla jsou zároveň autoetnografie nebo s etnografií vstupují do dialogu. V knize Auto/Ethnography: Rewriting the Self and the Social (Autoetnografie: Přepisování sebe sama a sociálna, 1997) nabízí antropoložka Deborah Reed-Danahayová širší definici autoetnografie, která zahrnuje tři překrývající se žánry: „domorodou antropologii“, v níž se autory studií vlastních skupin stávají lidé, kteří dříve bývali předmětem etnografického zkoumání, „etnickou autobiografii“, která je osobní výpovědí napsanou členem etnické menšiny, a „autobiografickou etnografii“, v níž antropologové vkládají osobní zkušenosti do etnografického psaní (Reed-Danahay 1997: 2). Podobně inkluzivní

17 Skutečnost, že antropologové čtou beletrii, je bohatě doložena například v Diary Bronisława Malinowského nebo v Stranger and Friend: The Way of the Anthropologist Hortense Powdermakerové. O antropolozích jakožto beletristických autorech hovoří Edward Bruner v úvodu k Anthropology and Literature, edit. Paul Benson (1993). Mezi nejzajímavější literární texty napsané antropology patří povídka "The Hot Spell“ Margery Wolfové vzniklá v pozdních 50. letech 20. století na Tchaj-wanu a otištěná ve sbírce $A$ Thrice Told Tale (1992), Return to Laughter: An Anthropological Novel (1964) Laury Bohannanové popisující její terénní práci v Nigérii a sbírka povídek Rhody Halperinové The Teacup Ministry and Other Stories (2001).

18 Sau-ling Cynthia Wongová problematizovala toto mainstreamové používání menšinové beletrie v eseji „Autobiography as Guided Chinatown Tour? Maxine Hong Kingston's The Woman Warrior and the Chinese American Autobiographical Controversy" (1992). Zatímco Kingstonové The Woman Warrior jistě není přímočará prohlídka čínské čtvrti, starší spisovatelé včetně Lina Yutanga, Pardeeho Lowea a Jade Snow Wongové cítili povinnost vystupovat jako průvodci po vlastních etnických enklávách, protože si uvědomovali, že píší pro většinově bílé publikum. 
popis autoetnografie vychází z díla Carolyn Ellisové a Arthura P. Bochnera, kteří propagují sebereflexivní psaní sociologů již od 90. let 20. století. Sebereflexivní beletrii z pera etnografů bychom snad měli odlišit od beletrie psané menšinovými spisovateli, kteří přistupují k etnografickému odkazu z pozice „objektu zájmu“, at už uplatňují právo zobrazovat sami sebe a svou komunitu, obracejí se čelem k etnografovi, nebo dekonstruují/nahrazují etnografické způsoby poznávání. Navrhuji následující prozatimní typologii žánrů:

(1) klasická etnografie (akademický text bílého Američana o neběloších);

(2) domorodá etnografie (akademický text původního obyvatele zkoumané kultury);

(3) etnografická beletrie (autobiografická beletrie psaná etnografem);

(4) menšinová beletrie, v níž vystupují antropologové, míněná jako kritika etnografie;

(5) autoetnografie (menšinový text, který do jisté míry odpovídá poptávce běžného čtenáře po autentické kulturní reprezentaci);

(6) kontra-etnografie (menšinová beletrie, která objektifikuje běžné Američany);

(7) parodická etnografie (humorná nápodoba etnografie);

(8) anti-etnografie (texty, které navrhují alternativy k etnografickým způsobům poznávání).

Některé texty spadají do několika kategorií zároveň a žádné dílo nelze redukovat na vzor jednoho konkrétního žánru.

Všechny tyto žánry je třeba chápat jako cesty k poznání. Etnografické cesty poznávání jsou otázkou úhlu pohledu, nikoli zásadního rozdílu. Jak tvrdí John Berger v knize Ways of Seeing (Způsoby vidění, 1977), to, co víme - stejně jako to, co vidíme -, je vždy kulturně podmíněno. Úhlu pohledu je třeba rozumět jako něčemu, co se mění a co je ovlivňováno kontextem, přestože souvisí se způsobem, jakým je prostřednictvím kulturních kategorií jako rasa, pohlaví, věk, (ne) schopnost nebo sexualita interpretováno lidské tělo. V knize z roku 1986 nazvané Women's Ways of Knowing (Ženské způsoby poznání), jejíž autorkou je Mary Field Belenkyová a kol., se píše, že americké ženy, bez ohledu na rasu a společenskou třídu, mají k poznání a k sobě jakožto vědoucí osobě odlišný vztah než muži (byt z historických důvodů). Poststrukturalistické feministky toto tvrzení problematizují, ale přesto se zajímají o „podřízené“ cesty k poznání, které jsou nedostatečně zastoupené ve středoporoudé literatuře, výtvarném umění i akademické obci. Feministické kritičky vědy, zejména Sandra Hardingová a Donna Harawayová, hledají kompromis mezi postrukturalistickým argumentem, že objektivita je falešný ideál, protože veškeré výroky založené na poznání jsou zásadním způsobem podmíněné, a hlubokým přesvědčením, že některá poznání jsou lepší než jiná (méně utiskující a prospěšnější pro marginalizované komunity, ženy, životní prostředí atd.). Ve své studii z roku 1991 o možnostech zavedení feministické epistemologie se Hardingová ptá: 
Kdo může být subjektem, agentem společensky legitimního poznání? (Pouze muži spadající do dominantní rasy a společenské tř́idy?) Jakými testy musí projít různá přesvědčení, aby byla uznaná za legitimní poznatky? (Pouze testy v rozporu se zkušeností a pozorováním dominantní skupiny?) [...] Jaké věci lze poznat? Lze „dějinnou pravdu“, sociálně situovanou pravdu počítat za poznání? Mělo by být veškeré takové poznání považováno za stejně věrohodné a platné? Jaká je povaha objektivity? Vyžaduje si nezastávat ani jeden z úhlů pohledu? [...] Může ve společnosti, kterou hluboce rozděluje pohlaví, rasa a společenská třída, existovat „nestranné poznáni“? (Harding 1991: 109-110)

Takové epistemologické otázky si lze klást teprve v posledních desetiletích, kdy dominantní paradigma pozitivistické vědy zpochybnil v roce 1962 Thomas Kuhn, kdy v 70. a 80. letech 20. století Michel Foucault přeinterpretoval mocenské mechanismy podpírající symbolické západní instituce a osvícenskou víru, kdy kritická masa žen a lidí jiné barvy pleti zastává významné funkce. Tyto otázky uspíšily koncepční posun, který - řečeno s Cliffordem - nenechal sociologům žádné vyvýšené místo, „odkud by mohli zobrazovat svět“ (Clifford Marcus 1986: 22).

Čteme-li Foucaultovy přednášky z roku 1976 o cirkulaci moci a vědění, můžeme vystavět podmanivý příběh - seismografický záznam událostí, který Clifford později popíše jako zemětřesení (Clifford - Marcus 1986). Foucault prohlašoval, že moc západních institucí, jako jsou nemocnice, věznice, ale také akademické obory, pochází „z produkce účinných nástrojů utváření a akumulace vědění - z observačních metod, způsobů zápisu, postupů prověřování a výzkumu, aparátů určených k ovládání. To vše znamená, že moc, je-li uplatňovaná pomocí těchto nenápadných mechanismů, nemůže rozvíjet, tř́ídit a šírit vědění, či spíše aparáty vědění, které nejsou ideologickým konstruktem.“ (Foucault 1980: 102) Ale hierarchický mocenský pořádek spojovaný s vědou podle Foucaulta ztrácí jistotu, protože „jsme svědky něčeho, co lze popsat jako povstání podř́zeného věděni“" (Foucault 1980: 81, zvýraznění v originálu). Toto náhle vyrašené vědění tu bylo vždy, uvnitř i vně institucí produkujících vědění, ale bylo systematicky diskvalifikováno jakožto „nehodné svého úkolu, či nedostatečně propracované“ (Foucault 1980: 82). Nyní si získává čím dál větší pozornost. Někdy jde o „erudované vědění“ pohřbené „v souboru funkcionalistické a systematizační teorie a odhalené zásluhou kritiky“, jindy o „naivní“ vědění psychiatrických pacientů a vězňů - a „domorodých informátorů“, dodala bych za etnografii. Nejen že je toto vědění osobité, lokální a diferencované, ale rovněž představuje kakofonii hlasů „neschopnou jednohlasnosti“ (Foucault 1980: 82). Tím je ovšem životnější, na rozdíl od spořádaných, dobře integrovaných legitimních diskurzů; náhle vyrašené vědění (někdy označované za „antivědu“) uchovává „,vzpomínky na nepřátelská setkání, která zůstávají do dnešního 
dne na okraji poznání“ (Foucault 1980: 83). Antagonismy a konflikt jsou katalyzátorem změny (jak později potvrdí Ernesto Laclau a Chantal Mouffeová), jimiž se máme řídit, místo abychom je urovnávali. Problém povstání spočívá v tom, že je lze př́liš snadno zneškodnit, varuje Foucault v poslední části tohoto př́iběhu. Jakmile je podřízené vědění „vykopáno“, „vyneseno na světlo“ [...], přijmuto a vysláno do oběhu, hrozí mu nebezpečí rekodifikace, rekolonizace“ pramenící z integrace do legitimního vědění (Foucault 1980: 86).

Foucaultův příběh o oslabování legitimního i podřízeného vědění oslovoval feministické poststrukturalistky, které se setkávaly na konferencích, četly a vzájemně komentovaly svou práci. Patřily mezi ně filozofky Sandra Hardingová, Donna Harawayová a Judith Butlerová i antropoložky Dorinne Kondová a Lila Abu-Lughodová. ${ }^{19}$ „Nechceme, aby teorie nevinné moci reprezentovala svět, kde jazyk a těla upadají do blaženosti organické symbiózy,“ napsala Harawayová v pojednání „Situated Knowledges“ (Situované poznání, 1988: 579). Při cizelování Foucaultových tezí trvala na tom, že „podřízenost není důvodem pro ontologii“; $z$ podřízeného stanoviska nelze zahlédnout nepodmíněnou vizi o nic víc než z jiných stanovisek (Haraway 1988: 586). Vlastníci vědění nesmí být esencializováni, ani romantizováni, protože „postavení podřízených nelze vyloučit z kritického přehodnocování, dekódování, dekonstrukce a interpretace. [...] Stanoviska podřízených nejsou ,nevinnými“ postoji“ (Haraway 1988: 584). Ale právě proto by podle Harawayové měla být náležitě oceněna. Podřízení vědí, že je jejich vědění okrajové, a proto je méně pravděpodobné, že podlehnou iluzi o objektivitě či univerzálnosti (Haraway 1988: 584).

Psaní Donny Harawayvé se pohybuje mezi filozofií a literaturou a neustále přichází s novými metaforami, které boří staré myšlenkové návyky. Mimoto se odvolává na literaturu jakožto na metaforu cest k poznání: na indiánské legendy o kojotech, Frankensteina Mary Shelleyové a konečně na teorii Katie Kingové o tom, jak „,básně“ vznikají na pomezí umění, byznysu a technologie. „Báseň“ by mohla docela dobře sloužit za model jistého neautoritativního, nepovýšeného, ztělesněného vědění, jaké Harawayovou zajímá:

Těla jakožto objekty poznání jsou materiálně-semiotické reprodukční nody, podobně jako „básně“, které jsou literární produkcí, v níž je jazyk hráčem nezávislým na intencích a autorovi. Hranice těl se zjevuji při sociální interakci. Hranice jsou rýsovány s pomocí mapovacích praktik; „objekty“ jako takové predem neexistují. Objekty jsou projektem hranic. Ale hranice se posunuji zevnitř; hranice jsou velmi ošidné. To, co dočasně ohraničují, zůstává schopné reprodukce významů a těl. Umístovat (vidět) hranice je riskantní. (Haraway 1988: 595, zvýrazněno v originálu) 
Také mnozí jiní akademici hledali v básni, divadelní hře, povídce či memoárech úlevu od předstírání vědeckého odstupu a objektivity, aniž se vzdávali vlastního vědění. Zatímco v minulosti muselo být takové porušení disciplíny utajené (proto antropologové často publikovali beletrii pod pseudonymem), ${ }^{20}$ dnes je považováno za novátorskou učenost. Dorinne Kondová při psaní o antropologii kombinuje teoretický esej, autobiografický narativ, rozhovor a divadelní hru. Jiné antropoložky, jako jsou Margery Wolfová, Edith Turnerová a Rhoda Halperinová, přeměnily své zkušenosti z terénu v povídky. A tak, mám-li použít Foucaultův slovník, jsme svědky mohutného nástupu náhle vyrašeného „erudovaného vědění“ ukotveného v autorské zkušenosti využité ke kritice funkcionalistické a systematizační teorie.

Literatura o sobě málokdy prohlašuje, že něco ví, přesto její sociální a vzdělávací funkce naznačuje, že v ní někteří čtenáři a učitelé vidí způsob, jak produkovat vědění. Jak v roce 1991 poznamenal Benedict Anderson, moderní národy se ve věci socializace občanů a budování komunity velice spoléhají na romány. Národní literatury se vyučují ve školách a jsou vnímány jako doplněk dějepisu. Etnické literatury, vyučované v rámci amerických multikulturních osnov, jsou jedním z prvků výchovy k občanství. Vstupují do dialogu s legitimnějším věděním a zpochybňují způsoby, jakými jsou získávány poznatky o skupinách mimo střední proud. A tak se zdá, že to, čemu Hardingová říká „dějinné pravdy“ nebo „sociálně situované pravdy“, lze počítat za druh poznání, jestliže se objeví ve formě literatury.

Jedním ze způsobů, jakými autoři literárních i etnografických textů získávají poznatky, je dialog (nebo klevetění) s druhými. Ale dialogický původ poznatků není v tradičních etnografických dílech patrný. „Participační pozorování“, které je denním chlebem etnografie, musí být doplněno klábosením - nenucenými hovory s informátory o jejich vlastním soukromém životě a o životech ostatních příslušníků jejich malé komunity. Člověk nemůže sestavit diagram příbuzenských vazeb, rekonstruovat mravní normy komunity a porozumět její spiritualitě, aniž klade osobní otázky, které by byly za jiných okolností považovány za nemístné. Marianna Torgovnická tuto zvláštnost pěkně ilustruje, když cituje pamětihodnou pasáž z Malinowského úvodu ke knize The Sexual Life of Savages (Sexuální život divochů), v níž autor vybízí čtenáře ke společné procházce po melanesijské vesnici:

Budeme sledovat několik [vesničanů] při milostných pletkách a při dojednávání manželských svazků; budeme strkat nos do domácích skandálů a projevíme indiskrétní zájem o jejich intimní život. Protože všichni byli po dlouhou dobu předmětem etnografického pozorování a mně se podařilo získat většinu materiálu díky

20 O literárních počinech antropologů pojednává John Van Maanen, Tales from the Field (1988); Richard Handler, Critics against Culture: Anthropological Observers of Mass Society (2005: $96-$ 122) a Barbara Tedlock, „Works and Wives: On the Sexual Division of Textual Labor" (1995). 
tomu, že ve mě měli důvěru a navíc a hlavně se rádi vzájemně pomlouvali. (Malinowski citován in Torgovnick 1990: 3)

Z tohoto úryvku kupodivu vyplývá, že vlezlost a klevetění ve jménu vědy je nejen přípustné, ale dokonce je to něco, co vědec (a následně čtenář) dělat musí. Malinowski jakožto původce metody participačního pozorování a jeden z prvních antropologů, kteří strávili v terénu dost času na to, aby si mohli povídat s „domorodci“ v jejich vlastním jazyce, musel tuto sebereflexi napsat z potřeby ukázat metodu sbírání dat jako přirozenou. Jestliže se jeho následovníci někdy cítili nepříjemně, mohli nad tím mávnout rukou, protože tou dobou už byla tato metoda v rámci oboru spolehlivě zavedená.

Teoretička a filmařka Minh-ha T. Trinhová vyjadřuje své výhrady vůči etnografickému způsobu poznávání a širření vědomostí o nezápadních národech velice jasně, když je označuje za akademicky posvěcené klepy. Tvrdí, že z postkoloniální perspektivy je etnografie pouhé klábosení s „domorodci“: je to konverzace západních akademiků o lidech, kteří jsou příhodně nepřítomní a nemohou tudíž odmlouvat. Trinhová zpochybňuje předpoklady, které se skrývají za takovými pasážemi, jako je ta výše zmíněná od Malinowského, a upozorňuje, že:

„naše“ konverzace, mezi „námi“ a o „nich“, je konverzací, v níž jsou „oni“ umlčeni. „Oni“ jsou vždy na druhé straně kopce, nazí a mlčenliví, ve své nepř́tomnosti stěži př́tomní. Jsou tématem diskuse, ale pouze tehdy, pustíme-li je mezi „sebe“, jsou-li předmětem debaty, jsou-li doprovázeni nebo predstavováni „námi“, kteří patříme do klubu, a proto jsou závislí a musí se chovat způsobně, aby si náš klub naklonili. [...] Antropologii konečně lépe vystihuje slovo „klepy“ (moc rádi spolu rozebíráme druhé) než „konverzace“ (diskuse o otázce), což je definice z dob Aristotela. (Trinh 1989: 67-68)

Etnografické texty obvykle nezmiňují specifika sběru dat (s výjimkou předmluv, úvodů a poznámek pod čarou) a vrhají se přímo k expozici a teorii. Abychom se dozvědělí více o úloze klábosení v etnografickém výzkumu, obratme se $\mathrm{k}$ manuálům pro terénní praxi nebo, ještě lépe, $\mathrm{k}$ autobiografiím a beletrii z pera etnografů. Podívejme se na etnografickou beletrii a uvidíme, jak různí autoři vydávají každodenní klábosení za sběr dat a jak se prezentace této praxe a výstupů z takového klevetění promění, jestliže předmětem zájmu nejsou negramotní obyvatelé izolované oblasti třetího světa, ale anglicky mluvící lidé, kteří by si jednou mohli přečíst, co o nich etnograf píše.

Přestože je výrok Trinhové o etnografii jakoby klábosení zjednodušený (a samozřejmě byl míněný jako provokace), zdá se mi užitečný, protože poukazuje na vztah mezi subjektem, objektem a čtenáři: kdo oslovuje koho a v čí (ne)přítomnosti? Jestliže čteme texty kvůli „drbům“, potom problematizujeme víru v tvưrčí psaní jakožto alternativu „realistické“ etnografie - způsob, jak se 
vyhnout objektifikaci, exotizaci, romantizaci a jinému zneužívání ostatních. Nechat „promlouvat podřízené“, abych použila termín Gayatri Spivakové, prostřednictvím etnografických textů, které budou dialogické či vícehlasé, nebo budou etnografovu vlastní autoritu podrývat jiným způsobem, nutně neznamená zrušit asymetrii mezi pozorovatelem a pozorovaným ve smyslu kontroly nad reprezentací (Spivak 1988).

Před jedním či dvěma stoletími se literatura a etnografie vzájemně doplňovaly a nebyly považovány za kvalitativně jiné druhy poznání. Potom vysoká literatura na nějakou dobu ztratila zájem zobrazovat společnost, zatímco etnografie se odřízla od literatury, jejíž doménou je subjektivita a singularita. V knize Navigators of the Contemporary: Why Ethnography Matters (Lodivodové současnosti: Proč je etnografie důležitá) shrnul David A. Westbrook aktuální situaci etnografie ve světě, kde „mapy nemají žádná prázdná bílá místa a ostrovů se nedostává“ (2008: 9), a došel k závěru, že víc ostrovů sice nejspíš nenalezneme, ale „okrajové oblasti tu budou vždy a úkolem etnografa je, nyní stejně jako dříve, podávat z těchto okrajových oblastí zprávu“, kdekoli je v současném světě objeví (2008: 10). Žádal antropology, aby se považovali za „lodivody“, kteří musí určit svou polohu ve vztahu k různým bodům sociální geografie a k narativům svých partnerů v dialogu (2008: 47). Výsledný text

by měl reflektovat danou situaci, ale nelze jej vnímat jako mechanickou reprodukci této situace, natož jako její zrcadlo. Surový etnografický materiál nebyl dřive, obecně vzato, dostupný a pramenil z diskusí a konverzací vedených etnografem. Data nemohou být $v$ důležitých ohledech reprodukována. Člověk může vést později jinou debatu, a to i s týmiž lidmi. V této poloze byl tedy pouze tento konkrétní lodivod, který se zapojil do hovoru, pozoroval, analyzoval a podal zprávu o tom, co viděl, neboli o konverzacích, jichž se zůčastnil a jež také z velké míry zinscenoval. Pouze tento lodivod může říct, že byl v tomto společenském prostoru přitomen a nacházel se na této křižovatce různých narativů. [...] Vyjádření etnografie k př́tomným situacím tudíz není popisem či reprezentací v běžném smyslu protože ty jsou z principu replikovatelné -, kdežto etnografická pozorování jsou z principu jedinečná. (Westbrook 2008: 64-65)

Jestliže lze Westbrookův hlas považovat za reprezentativní, potom je sblížení etnografie s literaturou na dohled. Aby byli etnografové ochotní připustit, že jejich zkušenost z terénu je výjimečná a jedinečná, že ke kulturám lze přistupovat pouze prostřednictvím partnerů $\mathrm{v}$ dialogu, kteří vyprávějí v odpověd' na otázky své příběhy, a že etnografové po návratu z terénu nedělají nic jiného, než že vytvářejí příběhy, musí se mnohé změnit. Někteří etnografové dnes 
cítí, že mají mnohem blíže $\mathrm{k}$ těm autorům beletrie, kteří dlouhodobě „podávají zprávy“ $\mathrm{z}$ okrajových oblastí, určují si polohu ve vztahu k různým partnerům v dialogu a intertextům a vymýšlejí způsoby, jak pochopit neustále se měnící sociální topografii. A příbuznost etnografie a fikce musí být rovněž uznána literární kritikou.

\section{Červenec 2016}

\section{Literatura}

Anderson, Benedict. 1991. Imagined Communities: Reflections on the Origin and Spread of Nationalism. Revised Edition ed. London and New York: Verso.

Appadurai, Arjun. 1988. Putting Hierarchy in its Place. Cultural Anthropology 3, 1: 36-49.

Attridge, Derek. 2004. The Singularity of Literature. London: Routledge.

Belenky, Mary Field et al. 1986. Women's Ways of Knowing: The Development of Self, Voice, and Mind. New York: Basic Books.

Behar, Ruth. 1996. The Vulnerable Observer: Anthropology That Breaks Your Heart. Boston: Beacon Press.

Benson, Paul (ed.). 1993. Anthropology and Literature. Urbana: University of Illinois Press.

Bentley, Nancy. 1995. The Ethnography of Manners: Hawthorne, James, Wharton. New York: Cambridge University Press.

Berger, John. 1977 [1972]. Ways of Seeing. London: Penguin.

Bernstein, Charles. 1992. A Poetics. Cambridge: Harvard University Press.

Buzard, James. 2003. On AutoEthnographic Authority. Yale Journal of Criticism 16, 1: 61-91.

Capetti, Carla. 1993. Writing Chicago: Modernism, Ethnography, and the Novel. New York: Columbia University Press.

Cheung, King-Kok. 2000. Words Matter: Conversations with Asian American Writers. Honolulu: University of Hawaii Press.

Clifford, James. 1986. Introduction. In: Clifford, James - Marcus, George E. (eds.): Writing Culture: The Poetics and Politics of Ethnography. Berkeley: University of California Press: 1-26. Clifford, James. 1988. Predicament of Culture: Twentieth-Century Ethnography, Literature and Art. Cambridge, Mass.: Harvard University Press.

Clifford, James. 1989. The Others: Beyond Salvage Paradigm. Third Text 3, 6: 73-78.

Clifford, James. 1997. Routes: Travel and Translation in the Late Twentieth Century. Cambridge, Mass.: Harvard University Press.

Clifford, James - Marcus, George E. (eds.). 1986. Writing Culture: The Poetics and Politics of Ethnography. Berkeley: University of California Press.

Culler, Jonathan. 1999. Anderson and the Novel. Diacritics 29, 4: 20-39.

Denning, Greg. 1980. Islands and Beaches: Discourse on a Silent Land, Marquesas 1774-1880. Melbourne: Melbourne University Press.

Edmond, Rod - Smith, Vanessa. 2003. Islands in History and Representation. London: Routledge.

Fabian, Johannes. 1983. Time and the Other: How Anthropology Makes Its Object. New York: Columbia University Press.

Ferens, Dominika. 2002. Edith and Winnifred Eaton: Chinatown Missions and Japanese Romances. Urbana: University of Illinois Press.

Fischer, Michael J. 1986. Ethnicity and the Post-Modern Arts of Memory. In: Clifford, James - Marcus, George E. (eds.): Writing Culture: The Poetics and Politics of Ethnography. Berkeley: University of California Press: 194-233. 
Foucault, Michel. 1980. Power/ Knowledge: Selected Interviews and Other Writings 1972-1977. Colin Gordon (ed.). Trans. Colin Gordon et al. Brighton: Harvester Press.

Geertz, Clifford. [1984] 2003. Anti AntiRelativism. In: Darnell, Regna (ed.): American Anthropology 1971-1995: Papers from the American Anthropologist. Lincoln: University of Nebraska Press: 416-439.

Handler, Richard. 2005. Critics against Culture: Anthropological Observers of Mass Society. Maridon: University of Wisconsin Press.

Haraway, Donna. 1988. Situated Knowledges: The Science Question in Feminism and the Privilege of Partial Perspective. Feminist Studies 14, 3: 575-599.

Harding, Sandra. 1991. Whose Science? Whose Knowledge? Thinking from Women's Lives. Ithaca: Cornell. Huang, Guiyou - Nelson, Emmanuel

S. (eds.). 2003. Asian American Short Story Writers: An A-to-Z Guide. Westport, CT: Greenwood Press. Keesing, Felix M. 1958. Cultural Anthropology: The Science of Custom. New York: Rinehart.

Keesing, Roger M. - Keesing, Felix M. 1971. New Perspectives in Cultural Anthropology. New York: Holt.

Kim, Elaine H. 1982. Asian American Literature: An Introduction to the Writings and Their Social Context. Philadelphia: Temple University Press. Loxley, Diana. 1990. Problematic Shores: Literature of Islands. London: Macmillan. Malinowski, Bronisław. 1984 [1922]. Argonauts of the Western Pacific: An Account of Native Enterprise and Adventure in the Archipelagoes of Melanesian New Guinea. Long Grove, Ill.: Waveland Press. Marcus, George E. - Fischer, Michael M. J. 1986. Anthropology as Cultural Critique: The Experimental Moment in the Human Sciences. Chicago: University of Chicago Press. Mead, Margaret. 1973 [1928]. Coming of Age in Samoa: A Psychological Study of
Primitive Youth for Western Civilization. New York: Morrow and Co.

Messerschmidt, Donald A. (ed.). 1981. Anthropologists at Home in North America: Methods and Issues in the Study of One's Own Society. Cambridge: Cambridge University Press.

Motzafi-Haller, Pnina. 1997. Writing Birthright: On Native Anthropologists and the Politics of Representation. In: Reed-Danahay, Deborah E. (ed.): Auto/ Ethnography: Rewriting the Self and the Social. Oxford: Berg: 195-222.

Nycz, Ryszard. 2006. Wprowadzenie. Kulturowa natura, słaby profesjonalizm. Kilka uwag o podmiocie poznania literackiego i statusie dyskursu literaturoznawczego. In: Markowski, Michał Paweł - Nycz, Ryszard (eds.): Kulturowa teoria literatury. Główne pojęcia i problemy. Kraków: Universitas.

Palumbo-Liu, David. 1995. Universalisms and Minority Culture. Differences 7, 1: 188-208.

Powdermaker, Hortense. 1966. Stranger and Friend: The Way of an Anthropologist. New York: W.W. Norton and Company.

Reed-Danahay, Deborah. 1997. Introduction. In: Reed-Danahay, Deborah E. (ed.): Auto/Ethnography: Rewriting the Self and the Social. Oxford: Berg: 1-17.

Rose, Dan. 1993. Ethnography as a Form of Life: The Written Word and the Work of the World. In: Benson, Paul (ed.): Anthropology and Literature. Urbana: University of Illinois Press: 192-224.

Spivak, Gayatri Chakravorty. 1988. Can the Subaltern Speak? In: Nelson, Cary - Grossberg, Lawrence (eds.): Marxism and the interpretation of Culture. Chicago: University of Illinois Press: 271-313.

Stocking, George W. 1992. The Ethnographer's Magic and Other Essays in the History of Anthropology. Madison: University of Wisconsin Press.

Tallman, Janet. 2002. The Ethnographic Novel: Finding the Insider's Voice. In: De Angelis, Rose (ed.): Between Anthropology and Literature: Interdisciplinary Discourse. London: Routledge: 11-22. 
Tedlock, Barbara. 1995. Works and Wives: On the Sexual Division of Textual Labor. In: Behar, Ruth - Gordon, Deborah A. (eds.): Women Writing Culture. Berkeley: University of California Press: 267-286.

Torgovnick, Marianna. 1990. Gone Primitive: Savage Intellects, Modern Lives. Chicago: University of Chicago Press.

Trinh, T. Minh-Ha. 1989. Woman, Native, Other: Writing Postcoloniality and Feminism. Bloomington: Indiana University Press.

Turner, Edith. 1993. Experience and Poetics in Anthropological Writing. In: Benson, Paul (ed.): Anthropology and Literature. Urbana: University of Illinois Press: 27-47.

Van Maanen, John. 1988. Tales of the Field: On Writing Ethnography. Chicago: University of Chicago Press.
Westbrook, David A. 2008. Navigators of the Contemporary: Why Ethnography Matters. Chicago: University of Chicago Press. Wolf, Margery. 1992. A Thrice-Told Tale: Feminism, Postmodernism, and Ethnographic Responsibility. Stanford: Stanford University Press.

Wong, Sau-ling Cynthia. 1992. Autobiography as Guided Chinatown Tour? Maxine Hong Kingston's The Woman Warrior and the Chinese American Autobiographical controversy. In: Payne, James Robert (ed.): Multicultural Autobiography: American Lives. Knoxville: University of Tennessee Press: 248-279.

Yu, Henry. 2001. Thinking Orientals: Contact and Exoticism in Modern America. New York: Oxford University Press. 